\title{
EFEKTIVITAS PENGGUNAAN MODEL INKUIRI TERBIMBING DENGAN METODE DEMONSTRASI DALAM MENINGKATKAN HASIL
}

\author{
Febrian Junaidy, Alfrits Komansilan, Jimmy Lolowang \\ Fakultas Matematika dan Ilmu Pengetahuan Alam, Universitas Negeri Manado \\ email: feeater25@gmail.com
}

\begin{abstract}
ABSTRAK
Penelitian ini terkait dengan penggunaan model inkuiry terbimbing dengan metode demonstrasi. Penelitian telah dilakukan untuk mengetahui sejauh mana ada peningkatan hasil belajar siswa setelah dilakukan tindakan kelas pembelajaran fisika dengan model inkuiry terbimbing menggunakan metode demonstrasi . Metode penelitian adalah metode penelitian tindakan kelas (PTK) yang diterapkan di kelas X SMK. Hasil penelitian menunjukkan bahwa tindakan pembelajaran dapat meningkatkan hasil belajar siswa. Peningkatan hasil belajar ini dapat dilihat dari adanya kenaikan nilai rata-rata pada siklus I dan Siklus II juga adanya peningkatan persentase ketuntasan belajar. Karena itu penggunaan model inkuiry tembimbing menggunakan metode demonstrasi dapat dijadikan alternative dalam pembelajaran IPA fisika di sekolah lanjutan atas.
\end{abstract}

Kata kunci: Hasil belajar, Inkuiri terbimbing, Demonstrasi

\section{ABSTRACT}

This research is related to the use of guided inquiry models with demonstration methods. Research has been conducted to determine the extent to which there is an increase in student learning outcomes after the physics learning class action is carried out with the guided inquiry model using the demonstration method. The research method is a classroom action research (CAR) method that is applied in class $X S M K$. The results showed that the action of learning can improve student learning outcomes. The increase in learning outcomes can be seen from the increase in the average value in the first cycle and second cycle also an increase in the percentage of mastery learning. Because of that the use of inquiry guidance models using demonstration methods can be used as an alternative in learning science physics in high school. Learning outcomes can be seen from the increase in the average value in the first cycle and second cycle also an increase in the percentage of mastery learning. Because of that the use of inquiry guidance models using demonstration methods can be used as an alternative in learning science physics in high school.

Keywords: Learning outcomes, Guided inquiry, Demonstration 


\section{PENDAHULUAN}

Pembelajaran merupakan proses pengembangan pengetahuan, keterampilan, atau sikap baru pada saat individu berinteraksi dengan informasi dan lingkungan. Konsep pembelajaran menurut Rustaman, N.Y, dkk. 2003 adalah suatu proses dimana lingkungan seseorang secara disengaja dikelolah untuk memungkinkan ia turut serta dalam tingkah laku tertentu dalam kondisikondisi khusus atau menghasilkan respons terhadap situasi tertentu, pembelajaran merupakan subset khusus dari pendidikan.

Fisika sebagai salah satu cabang IPA, mempelajari dan menganalisis secara kuantitatif gejala atau proses alam. Fisika merupakan ilmu pengetahuan yang mempelajari bagian-bagian alam dan interaksi yang ada di dalamnya. Melalui interaksi ini, ilmu fisika membantu mengungkap dan memahami tabir misteri alam semesta. Selain itu, pelajaran fisika merupakan pelajaran yang memberikan pengetahuan tentang alam semesta untuk berlatih berpikir dan bernalar, melalui kemampuan penalaran seseorang yang terus dilatih sehingga semakin berkembang, maka orang tersebut akan bertambah daya pikir dan pengetahuannya (Supardi, 2012). Atas dasar inilah Fisika mutlak wajib diajarkan pada setiap siswa. Fenomena tersebut merupakan masalah yang serius dan perlu mendapatkan perhatian penuh dari semua pihak, baik pemerintah, sekolah, masyarakat/ orang tua maupun siswa itu sendiri.

Keberhasilan pendidikan sangat tergantung pada unsur manusia sebagai pelakasana yaitu guru dan siswa serta sarana dan prasarana atau alat evaluasi semuanya merupakan faktor yang pada hakekatnya memliki kewenangan untuk menentukan dan melaksanakan kegiatan proses belajar mengajar. Tentunya perlu ada kesiapankesiapan belajar mengajar antara guru dengan siswa dalam mencapai hasil belajar siswa. Salah satu komponen yang harus dipertimbangkan untuk mencapai keberhasilan pendidikan adalah peningkatan kompetensi guru .

Dalam hal kegiatan belajar mengajar, dan lebih khusus dalam pembelajaran mata pelajaran fisika, kebanyakan orang beranggapan bahwa mata pelajaran fisika sukar untuk dipahami, oleh karena karakteristik materi fisika sarat dengan rumus dan penurunan rumus itu sendiri rumit demikian halnya banyak konsep yang abstrak. Jika guru tidak memiliki kemampuan professional dibidangnya maka hal ini yang menyebabkan proses pembelajaran dikelas tidak akan berjalan sebagaimana yang diharapkan. Guru harus menempuh langkah-langkah dalam rangka menciptakan suasana belajar yang menantang, membangkitkan semangat, kreativitas, produktivitas dan mandiri. Para guru harus mampu mengembangkan strategi pembelajaran agar memberi peluang dan ruang kepada siswa menguasai kompetensi yang harus dimilikinya. Dalam implementasi kegiatan belajar mengajar guru harus mampu menempatkan diri sebagai fasilitator, sambil mempertimbangkan kemampuan awal siswa dan kebutuhan siswa, karena yang ingin dicapai adalah keberhasilan siswa/peserta didik di sekolah.

SMA Tompaso adalah sekolah yang berupaya menghasilkan anak didik yang Kreatif dan inovatif. Setiap siswa memiliki karakter/kepribadian dan kemampuan intelektual yang berbeda satu dengan yang lainnya. Pebedaan tersebut menjadi suatu hambatan bagi siswa yang memiliki motivasi rendah dalam belajar untuk dapat memahami sepenuhnya pelajaran yang diberikan. Berdasarkan hasil observasi dari peneliti suasana belajar siswa kelas XI IPA SMA Negeri Tompaso untuk mata pelajaran Fisika, metode pembelajaran yang digunakan oleh guru masih bersifat searah dimana antara lain, proses belajar mengajar hanya berorientasi pada buku yaitu siswa hanya diberi tugas untuk mencatat materi yang akan dipelajari kemudian diberi sedikit penjelasan dan tugas mandiri sehingga tidak tercipta suasana yang baik antara guru dengan siswa maupun siswa dengan siswa.

Metode pembelajaran ceramah yang digunakan guru SMA Negeri Tompaso pada mata pelajaran Fisika hanya sedikit berdampak untuk membawa anak didik pada pengetahuan baru. Kurangnya kegiatan praktikum yang dilakukan oleh guru mata pelajaran karena keterbatasan alat-alat praktikum di laboratorium membuat siswa hanya mengirangira setiap konsep Fisika yang abstrak, tanpa mengetahui dengan pasti karena mereka tidak dapat melihat dan membuktikan secara langsung. Dengan metode yang ada mengakibatkan rasa tidak percaya diri siswa untuk melakukan komunikasi dengan guru 
sehingga siswa menjadi pasif, yang akhirnya mengakibatkan rendahnya hasil belajar siswa, hal ini dilihat dari hasil belajar siswa kelas XI IPA yang tidak mencapai nilai standard ketuntasan suatu mata pelajaran yakni nilai yang menjadi KKM di sekolah yaitu 75 . Padahal mata pelajaran Fisika didalamnya terdapat teori dan memerlukan kegiatan praktikum, sehingga peneliti menganggap perlu diadakan suatu metode pembelajaran yang kreatif dan inovatif dalam rangka upaya efektifitas hasil belajar yang baik.

Metode demonstrasi merupakan salah satu metode yang dapat digunakan untuk meningkatkan hasil belajar siswa dimana metode demonstrasi adalah metode mengajar dengan cara memperagakan barang, kejadian, aturan, dan urutan melakukan suatu kegiatan, baik secara langsung maupun melalui penggunaan media pengajaran yang relevan dengan pokok bahasan atau materi yang sedang disajikan (Muhibbin Syah, 2000:22). Model pembelakajaran Inkuiri juga merupakan salah satu model yang dapat meningkatkan hasil belajar siswa dan sangat cocok untuk dipadukan dengan metode demonstrasi. Elliot Seif mendefinisikan inkuiri sebagai proses menemukan sesuatu dan memecahkan masalah. Model pembelajaran inkuiri merupakan suatu rangkaian kegiatan belajar yang melibatkan secara maksimal seluruh kemampuan siswa untuk mencari dan menyelidiki secara sistematis, kritis, logis, analitis, sehingga mereka mampu merumuskan sendiri penemuannya dengan penuh percaya diri.

Pembelajaran fisika untuk topik fluida di kelas XI IPA SMA akan sangat efektif bila menggunakan metode demonstrasi karena alat/ materi demonstrasi mudah diperoleh dilingkungan sekitarnya, sehingga keterbatasan alat praktikum yang ada di sekolah tidak akan menjadi masalah, dilengkapi dengan model inkuiri secara terbimbing, sehingga siswa dapat memperoleh petunjuk-petunjuk berupa pertanyaan-pertanyaan seperlunya yang bersifat membimbing siswa selama mengamati demonstrasi. Seperti untuk menjelaskan pengaruh diterjen terhadap tegangan permukaan dapat diambil benda sembarang seperti sebuah silet, gelas minuman, air secukupnya, dan diterjen secukupnya. Guru dengan mudah mendemonstrasikan, dengan meletakkan silet di permukaan air, sehingga siswa dapat melihat adanya tegangan permukaan. Kemudian pada gelas minuman yang lain tambahkan diterjen pada air, lalu letakkan silet seperti semula, sehingga siswa dapat melihat pengaruh diterjen pada tegangan permukaan. Dan banyak lagi fenomena fluida yang dapat diamati di lingkungan sekitar siswa.

\section{METODE PENELITIAN}

Jenis penelitian ini adalah Penelitian Tindakan Kelas (PTK). Penelitian tindakan kelas merupakan serangkaian penelitian yang dilakukan secara siklik yang bertujuan untuk memperbaiki kinerja, bersifat kontekstual, dan hasilnya tidak untuk digeneralisasikan. Peneliti terlibat langsung dalam tahap perencanaan, pelaksanaan, observasi dan refleksi. Penelitian tindakan kelas juga berfokus pada kelas atau proses pembelajaran yang terjadi di kelas yang harus tertuju atau mengkaji hal-hal yang terjadi dalam kelas. Subjek data penelitian ini adalah peserta didik yang terdiri dari 24 orang kelas $\mathrm{X}$ SMK Tombatu. Penelitian dilaksanakan pada semester genap 2017/2018 dengan menyesuaikan jam pelajaran pada semester ganjil. Instrumen data yang digunakan adalah: tes hasil belajar fisika, tes yang digunakan mengukur hasil belajar peserta didik. Adapun indikator penelitian tindakan kelas ini dikatakan berhasil apabila terjadi peningkatan skor hasil belajar peserta didik pada aspek kognitif/pengetahuan. Perlakuan dianggap berhasil bila diperoleh hasil ketuntasan belajar secara klassikal mencapai $\geq 70 \%$ dari skor ideal atau skor tertinggi yang diperoleh siswa.

\section{HASIL DAN PEMBAHASAN Hasil Pembelajaran di Siklus I}

Pelaksanaan kegiatan belajar mengajar pada siklus I dimulai dengan menyampaikan kompetensi yang akan menjadi tujuan pembelajaran. Dalam siklus I ini, memerlukan waktu 6 x 40 menit. Kegiatan belajar mengajar dilaksanakan mengikuti Rencana Pelaksanaan Pembelajaran (RPP) yang sudah disusun. Dalam proses belajar, siswa dituntun oleh Lembar Kerja Siswa (LKS) dan demonstrasi yang dilakukan oleh guru. Pada pertemuan pertama, guru mengondisikan siswa agar siap melaksanakan proses pembelajaran dengan menjelaskan topik, tujuan dan hasil belajar yang diharapkan dapat dicapai oleh siswa, menjelaskan pokok-pokok kegiatan yang harus dilakukan siswa untuk mencapai tujuan pembelajaran serta mulai mengajak siswa untuk 
berpikir memecahkan masalah melalui demonstrasi sederhana yang ditampilkan di awal pembelajaran. Pada pertemuan kedua, siswa mulai melakukan praktikum sederhana dengan topik "tekanan hidrostatik" dan demonstrasi hukum Bernouli 1 di mana siswa diajak untuk merumuskan sendiri masalah yang ditemui serta merumuskan hipotesis sendiri. Pada siklus 2, siswa melakukan suatu demonstrasi hukum Bernolli 2". Untuk setiap pertemuan, setelah proses belajar mengajar selesai guru memeriksa hasil LKS yang telah dikerjakan oleh siswa dan memberi komentar serta memperbaiki jawaban siswa yang belum benar. Evaluasi dilakukan setiap pertemuan dimana pada siklus satu ada 3 kali pertemuan untuk memperoleh data tentang kemampuan siswa dalam menguasai konsep sains fisika yang diajarkan. Hasil tes dapat ditampilkan dalam gambar berikut:

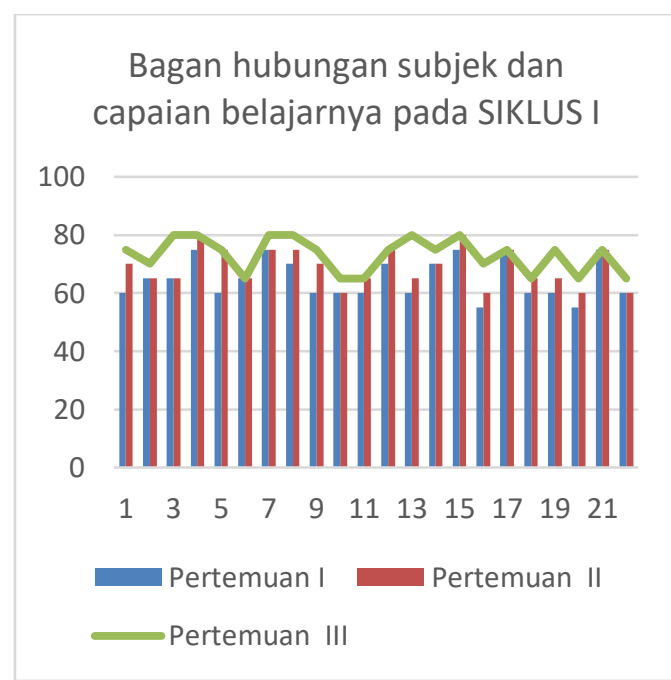

Gambar 1. Bagan Capaian Belajar Siklus I

Tabel 1. Data Statistik Siklus I

\begin{tabular}{cccc}
\hline \multirow{2}{*}{ Nilai } & \multicolumn{3}{c}{ PERTEMUAN } \\
\cline { 2 - 4 } & I & II & III \\
\hline Terendah & 60 & 60 & 65 \\
\hline Tertinggi & 75 & 80 & 80 \\
\hline Rata-rata & 65 & 68,86 & 93,18 \\
\hline$\%$ & 36,36 & 50,00 & 77,27 \\
Ketuntasan & & & \\
\hline
\end{tabular}

\section{Refleksi Pelaksanaan Kegiatan Belajar Mengajar Siklus I}

Tindakan pembelajaran yang dilakukan di siklus I cukup berhasil karena berdasarkan data pada gambar.4.1, penguasaan siswa tentang konsep fluida terus meningkat mulai pertemuan pertama sampai dengan pertemuan ke tiga.
Demikian halnya nilai-rata-rata dan ketuntasan belajar juga meningkat. Beberapa hal yang menjadi catatan refleksi adalah pada pertemuan pertama antusias siswa untuk belajar belum baik, namun setelah pembimbingan dimaksimalkan berangsur-angsur motivasi dan dorongan untuk berusaha mendapatkan yang terbaik mulai muncul, dan hal ini terlihat dari kecenderungan kenaikan capaian belajar siswa. Pada pertemuan pertama dilakukan tes tertulis, hasilnya seperti yang ditunjukkan pada gambar 4.1. di mana terdapat 17 siswa yang memperoleh nilai $<75$ dari 22 siswa artinya, tingkat penguasaan konsep siswa pada pertemuan pertama hanya $22,73 \%$. Hal ini mengindikasikan bahwa sebagian besar siswa belum menguasai materi tentang fluida. Namun pada pertemuan II dan III tingkat penguasaan konsep fluida mulai membaik. Hal ini bukan berarti berhenti sampai disini namun perlu dioptimalkan pembelajarannya untuk meningkatkan nilai capaian siswa, mengingat belum $100 \%$ siswa tuntas belajar.

\section{Pelaksanaan Kegiatan Belajar Mengajar (KBM) siklus II}

Pelaksanaan kegiatan belajar mengajar pada siklus II dimulai dengan menyampaikan kompetensi yang akan menjadi tujuan pembelajaran. Kemudian, guru mengaitkan materi baru dengan materi yang diajarkan sebelumnya, dilanjutkan dengan tanya jawab dan demonstrasi untuk memotivasi siswa dan menanamkan daya tarik siswa terhadap materi yang diajarkan.

Berdasarkan pengalaman pada kegiatan belajar mengajar sikulus I, ada beberapa hal yang perlu diperhatikan sebelum memasuki kegiatan belajar mengajar siklus II, yaitu:

1. Memastikan bahwa semua perlengkapan pembelajaran yang dibutuhkan telah tersedia.

2. Penyusunan LKS untuk siklus II dibuat sederhana dan praktis agar mudah dipahami oleh siswa.

3. Mendorong minat siswa dalam kerja kelompok.

4. Meningkatkan keaktifan siswa dalam bertanya.

5. Lebih meningkatkan tahap - tahap inkuiri dalam proses pembelajaran.

6. Mendorong agar interaksi siswa dengan guru dan antar siswa dapat ditingkatkan.

7. Mengusahakan agar siswa tidak melihat contoh dalam buku ketika hendak 
menjawab pertanyaan dalam LKS maupun dalam mengerjakan soal yang diberikan.

8. Hasil kerja siswa pada siklus I yang telah diperiksa oleh guru dikembalikan kepada siswa dan guru menjelaskan hal - hal yang menjadi kekurangan dalam kegiatan belajar mengajar di siklus I.

Pada pertemuan keempat pada siklus II, selain meminimalisasi kendala di siklus I, juga proses keterlibatan siswa perlu dioptimalkan. Siswa - siswa yang belum tuntas pada proses belajar mengajar siklus I diberi tugas tambahan berkaitan dengan materi yang mereka belum kuasai. Pada pertemuan keempat di siklus II, bahan ajar yang diberikan adalah Hukum Bernouli 2. Sementara pada pertemuan kelima, materi yang diberikan adalah Perpindahan Fluida dan Pemanfaatannya. LKS yang didesain diharapkan dapat menuntun siswa mendapatkan pemahaman yang lebih baik dari sebelumnya. Setelah melakukan kegiatan belajar mengajar pada pertemuan keempat dan kelima, hasil penelitian pada siklus II menunjukkan hasil yang lebih baik dibandingkan dengan hasil pada siklus I. Dalam pengisian LKS, proses keterlibatan siswa menunjukkan angka persentase $>75 \%$ artinya siswa mampu mengisi LKS sesuai dengan langkah - langkah inkuiri yang diharapkan. Siklus II hanya dilakukan dua kali pertemuan dengan hasil yang dirangkum sebagai berikut:

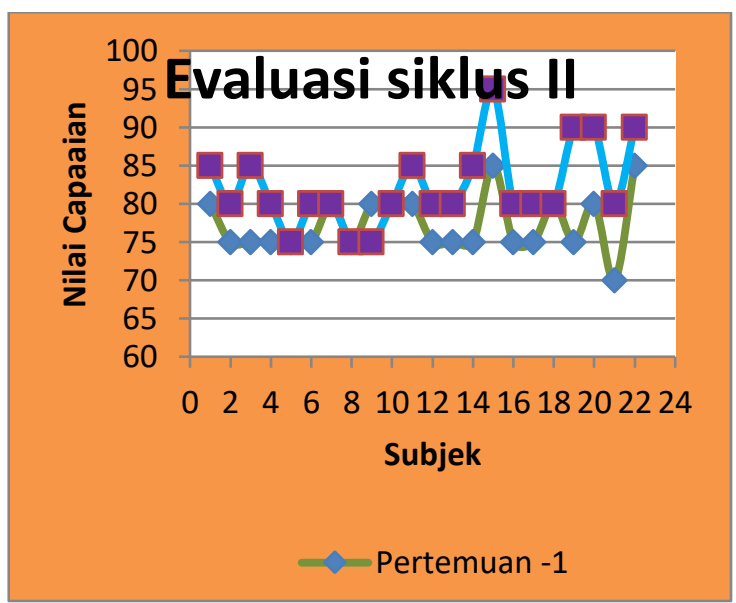

Gambar 2. Grafik Evaluasi Siklus II

\section{Refleksi Pelaksanaan Siklus II}

Hasil pelaksanaan pembelajaran menggunakan model inkuiri terbimbing pada siklus II setelah memperhatikan pengalaman pada siklus I, maka hasilnya dapat dilihat pada gambar 2. Data pada gambar 2 menunjukkan bahwa secara individu seluruh siswa sudah mencapai nilai kriteria ketuntasan minimal pada pertemuan keempat dimana tingkat penguasaan konsep siswa adalah $100 \%$, namun nilai rata rata masih pada pertemuan 4 lebih kecil dibandingkan dengan nilai rata-rata pertemuan ke 5. Sementara itu, pada pertemuan kelima tingkat penguasaan konsep siswa mengalami peningkatan menjadi $100 \%$. Nilai $100 \%$ menunjukkan bahwa seluruh siswa mendapat nilai di atas kriteria ketuntasan minimal yang ditetapkan sekolah yakni 70 . Pada pertemuan ini semuanya mendapat nilai $\geq 70$ dan 1 orang mencapai nilai tertinggi 95 .

Hasil yang didapatkan pada siklus II ini menunjukkan bahwa tingkat penguasaan konsep siswa mengalami peningkatan.

\section{Pembahasan}

Secara umum, tingkat penguasaan konsep siswa pada siklus I belum memberikan hasil yang memuaskan. Sebagaimana penjelasan pada refleksi siklus I, beberapa siswa masih memperoleh nilai di bawah dari KKM $(<75)$ .Hal ini mungkin disebabkan oleh siswa yang terbiasa dengan pola dan gaya mengajar gurunya, ketika terjadi pergantian guru dengan model pembelajaran yang berbeda maka perlu penyesuaian - penyesuaian dan belum memberikan kontribusi positif pada kegiatan diskusi dan proses belajar lainnya.

Berdasarkan grafik gambar 4.2. tersebut, kita langsung dapat membandingkan hasil yang diperoleh siswa pada pertemuan keempat dan kelima dimana ada peningkatan penguasaan konsep setelah adanya tindakan dalam pertemuan IV dan ke V. Hal penting dalam table 4.3 menunjukkan bahwa ketuntasan belajar siswa meningkat masing-masing $100 \%$ di pertemuan 4 dan di pertemuan 5. Hal inilah yang membuat peneliti menyimpulkan bahwa dengan capaian ketuntasan belajar 100\% dalam arti seluruh siswa sudah mendapat nilai sama atau lebih besar 70, dan menunjukkan bahwa penggunaan metode inquiri terbimbing berbasis demonstrasi efektif.

Aulia S. (2013) dalam penelitiannya menjelaskan bahwa ada perbedaan hasil belajar siswa sebelum dan setelah diberi perlakuan model guided inquiry. Gambar berikut menunjukkan peningkatan prosentase ketuntasan belajar ssiwa yang memberi informasi bahwa penggunaan model pembelajaran inhuiri terbimbing berbasis 
demonstrasi efektif dalam meningkatkan pengusaan konsep siswa pada materi Fluida.

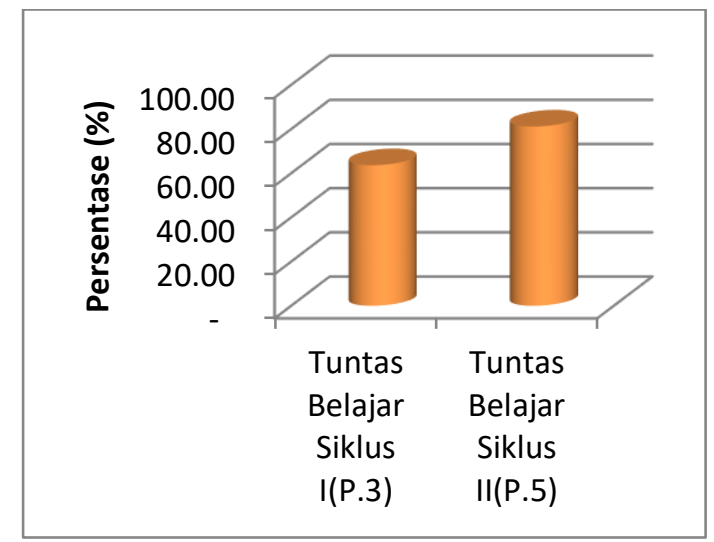

Gambar 3. Bagan Ketuntasan Belajar

Beberapa hal yang menjadikan model pembelajaran inkuiri terbimbing cukup berhasil antara lain : Persiapan dari guru yang cukup baik demikian halnya perlengkapan pembelajaran dipersiapkan dengan baik. Penyajian materi juga dituntun dengan menggunakan LKS yang mampu membangkitkan rasa ingin tahu siswa, gairah belajar siswa, motivasi belajar siswa, keterlibatan siswa, serta kreatifitas siswa di mana hal ini terlihat ketika siswa mengerjakan LKS maupun soal yang diberikan. Penggunaan model pembelajaran inkuiri terbimbing juga membuat siswa dapat belajar dengan santai, nyaman dan menyenangkan karena memungkinkan siswa belajar dengan memanfaatkan berbagai jenis sumber yang tidak hanya menjadikan guru sebagai satu satunya sumber belajar. Selain itu, dengan penerapan model pembelajaran ini siswa lebih termotivasi untuk berpikir kreatif dan merumuskan sendiri hipotesisnya. Hal ini tentu hal ini mendorong siswa untuk membentuk dan mengembangkan konsep sendiri sehingga secara psikologi siswa lebih terbuka terhadap pengalaman baru, berkeinginan untuk selalu mengambil dan memanfaatkan kesempatan kesempatan yang ada. Diskusi siswa dalam kelompok sangat bergantung pada siapa anggota kelompok. Jika anggota kelompok memiliki kemampuan di bawah rata-rata maka diskusi memakan waktu lama.

\section{KESIMPULAN}

Berdasarkan hasil yang diperoleh, dapat disimpulkan bahwa metode demonstrasi berorientasi inkuiri terbimbing pada topik
Fluida dapat meningkatkan hasil belajar Fisika siswa kelas XI IPA di SMA Negeri I Tompaso.

\section{REFERENSI}

Arikunto, S, Suhardjono, Supardi. (2012).Penelitian Tindakan Kelas. Bumi Aksara: Jakarta

Aulia E,V, Poedjiastoeti.2018. The Effectiveness of Guided Inquiry-based Learning Material on Students' Science Literacy Skill. Journal of Physics Conference Series 947(1):012049

Aulia Sanova.2013. Model Pembelajaran Inkuiri Terbimbing melalui Metode Eksperimen dan Demonstrasi Ditinjau dari Gaya dan Minat Belajar. Jurnal Penelitian Universitas Jambi: Seri Humaniora • 2013

I.G.A.K. Wardani, (2004). Penelitian Tindakan Kelas. Jakarta: Pusat Penerbitan UT

Muhibbin Syah, (2000). Psikologi Belajar. Jakarta: Raja Grafindo Persada

Rustaman, N.Y, dkk. 2003. Strategi Belajar Mengajar Biologi. Bandung: Jurusan

Pendidikan Biologi UPI

Saeed Sakeh A., Robiyn Gillies. 2016. The Effectiveness of a Guided Inquiry-based, Teachers' Professional Development Programme on Saudi Students' Understanding of Density. 